\title{
Marxism, Communism, Marxian Socio-political Economic Theory and the Socialist World: Part-I
}

\author{
M.L. Sehgal \\ Ex: D.A.V. College, Jalandhar, Punjab (India)
}

\begin{abstract}
Marxian model of economic, as enunciated in "Das-Capital" disapproved of the two classical models of economics proposed by Adam Smith and John Maynard Keynes though both had stood the test of the time. Marx's Economic Theory encompassed the social, historical, and economic points of view based upon the thesis of Hegel's philosophy as well as its antithesis. Marx believed that the concept of relations of production as proposed by Capitalism was vague for the socio-cultural set up of a society. He said that Capitalism would not end up in a quiet death; rather it would have to be broken up with a 'Bang'; maybe by Violent Revolution. Rather than giving some weightage to machines, the paper, or the 'capital', Marx would put all his eggs on the 'Labor Class' as he opined that the 'Capitalist Class' exploits the Labor Class. He would proclaim that the sole factor which decided the prices of the commodities was the value of the labor as determined by Labor Theory of Value (LTV) and not by the cost of machines and the capital put in for running the various operation of the establishment. There would be no Ownership of property; State becoming the sole proprietor as everything will be nationalized. Countries like the USSR and East Germany, after being separated from West Germany, because of the execution of treaties of WW-II (1945). North Vietnam, North Korea, Cuba, and Venezuela also turned Socialists. Their economies (GDPs) will make a part of the present study. Poland, Czechoslovakia, Hungry, and China, which also followed the Socialistic pattern, are excluded.
\end{abstract}

Keywords: Das-Capital', Capitalism, Socialism, Two Classes, Classless Society, Class Conflict, Bourgeoisie, Proletariat, Capitalist Mode of Production, Labor Theory of Value, Surplus Value, Falling Rate of Profit, 'The Big Three', East and West Germany, Russia North and South Vietnam, North and South Korea, Cuba, Venezuela

\section{INTRODUCTION}

It is not possible to make a full and comprehensive evaluation of Marx's Economic Theory just in one article. So we have divided it into two parts.

\section{Marx and Engels}

Karl Marx (5 May 1818 -14 March 1883) was a German philosopher, Economist, Historian Sociologist, Political Theorist, Journalist, and above all a Socialist-Revolutionary. Initially, his works were more of philosophical and political nature but after his exile in London (1849), he got 
infatuated towards the economic thought are a series of notes written between April and August 1844 by Karl Marx. [1] Not published by Marx during his lifetime, they were first released in 1932 by researchers in the Soviet Union) and brought about the volumes and manuscripts of Das Kapital. $[2,3,4]$ But, Marx could not find time to present his philosophy in a proper format. Rather, it was lying bare in the form of several briefs; though very suggestive passages [5] It was left to others; especially, Frederick Engels, a German (28 November 1820- 5 August 1895) to compile Marx's works (Engels, 1884, 1886, 1894) to almost equal to that of the writings of Marx himself. [3, 4]. While Marx did not live to publish the planned second and third parts of Das Kapital (German equivalent of Capital), they were both completed from his notes and published after his death by Friedrich Engels. Engels et.al compiled the Volume: II and III entitled Marx's Das Kapital. [6]

\section{Capital Volume I: The Process of Production of Capital}

Only this volume of Das Kapital was published in Marx's lifetime in 1867. It is a critical analysis of capitalism as political economy, meant to reveal the economic laws of the capitalist mode of production, how it was the precursor of the socialist mode of production, and the class struggle rooted in the capitalist social relations of production.

\section{Volume II: Subtitled as "The Process of Circulation of Capital”}

Capital Volume II and Das Kapital are both written by Karl Marx. But this second of three volumes of Das Kapital (German equivalent- Kritik der politischen Ökonomie) was prepared by Friedrich Engels from notes left by Karl Marx and published in 1885. It is divided into three parts:

1. The Metamorphoses of Capital and Their Circuits

2. The Turnover of Capital

3. The Reproduction and Circulation of the Aggregate Social Capital

It contains main ideas behind the marketplace that are to be found as to how value and surplusvalue are realized. Its dramatis personae, not so much the worker and the industrialist, but rather the money owner, the wholesale merchant, the trader and the entrepreneur, or 'functioning capitalist.' Moreover, workers appear in Volume II, essentially as buyers of consumer goods and, therefore, as sellers of the commodity labor-power, rather than producers of value and surplusvalue.

\section{Capital, Volume III: Subtitled The Process of Capitalist Production as a Whole}

It is the third volume of Das Kapital (Kritik der politischen Ökonomie). It was prepared by Friedrich Engels from notes left by Karl Marx and published in 1894.

It consists of seven parts:

1. Part I (7 Chapters) Conversion of Surplus-Value into Profit and of the Rate of Surplus-Value into the Rate of Profit

2. Part II (5 Chapters) Conversion of Profit into Average Profit

3. Part III (3 Chapters) Law of the Tendency of the Rate of Profit to Fall

4. Part IV (5 Chapters) Conversion of Commodity-Capital and Money-Capital into Commercial Capital and Money-Dealing Capital (Merchant's Capital)

5. Part V (16 Chapters) Division of Profit into Interest and Profit of Enterprise.InterestBearing Capital 
Sehgal, M. L. (2020). Marxism, Communism, Marxian Socio-political Economic Theory and the Socialist World: Part-I. Advances in Social Sciences Research Journal, 7(5) 70-90.

6. Part VI (11Chapters) Transformation of Surplus-Profit into Ground-Rent

7. Part VII (5 Chapters) Revenues and their Sources

So together, they contain a total of 52 chapters. Also, there is Frederick Engels's Supplement to Capital, Volume III- which consists of three chapters as follows:

1. Introduction

2. The Law of Value and Rate of Profit

3. The Stock Exchange

Defining Marxism
Neither Marx nor Engels used the term called 'Marxism'. Rather, Engels reports that Marx responded
to its use by Lafargue [7, 8] by saying 'all I know is that I am not a Marxist'[91. The term 'Marxism'
was first employed by Marx's opponents in the socialist movement during the 1870s and 1880s.
Towards the end of Engels' life, however, the term began to be used by the followers as well as
opponents of Marx, and this usage rapidly gained acceptance.
The system of thought- a doctrine (Excluding Leninism and Maoism) created by Marx and Engels has
been named as "Marxism”[10] which started with the harbinger of many hopes and dreams to liberate
the human race, especially workers from poverty and oppression, to ultimately make them the master
of their means of production, to give them a better decision on how and what to produce and what to
do with the surplus, to prevent the alienation of workers and their products and put forward the
political, economic, and social principles and policies where workers will have a greater say in how
the political and economic system operates, to do away with the delusion of Democracy and to change
it with Direct Democracy, abolishing Capitalism, advocating a theory and practice of socialism, the
labor theory of value, dialectical(real-world conditions) materialism, the class struggle, and a
dictatorship of the proletariat until the establishment of a classless society.[11]
Defining Communism
(a) 'It is a theory or system of social organization in which all property is owned by the community
and each person contributes and receives according to their ability and needs'.
(b). It was first used in the mid-19th century when it was referred to as economic and political theory
that advocated the elimination of private property and the common sharing of all resources among a
group of people. Nowadays the word communism usually refers to the political and economic
ideologies originating from Karl Marx's theory of revolutionary socialism, which advocates a
proletariat overthrow of capitalist structures within society; societal and communal ownership and
governance of the means of production; and the eventual establishment of a classless society.
(c). Communism is a form of government that falls on the socialism spectrum.[12]

\section{METHODOLOGY}

The research material on Marx/Marxism/ Communism was collected both from the official and nonofficial agencies. A historical and analytical approach was taken into consideration while using primary and secondary sources. The primary sources are available at the National Archives of India, Delhi, Punjab State Archives, Chandigarh, Punjab State Archives, Patiala, Dwarka Das Library, Chandigarh and The Museum Library, Delhi. Among the important official documents, mention was made of some, such as IMF, World Bank, W. H. O., The Modern Review, and Asiatic Review. The secondary sources such as the relevant Journals, newspapers, magazines, articles, books especially the three volumes of 'Das Kapital', 'The Wealth of Nations' and 'General Theory of Employment, Interest, and Money', the frequent use of the internet for the updated material as well as published theses were assessed to present an objective work as far as possible. 


\section{DISCUSSION}

\section{Socio-Economic Theory of Marx}

The main points of Marx's Economic Theory are:

Marx wrote that he aimed to:

"Lay bare the economic law of motion of society".[7]

\section{Capitalism, Classes, Class Conflict, and Socialism: All Interrelated}

Marx defined capitalism as a mode of production characterized by the separation of the direct producers, the working class, from the means of production or the productive assets, which are controlled by the Bourgeoisie (who are):

'The Ruling Class in society who control the means of production, such as capitalists and large employers, and, according to Marxist theory,oppress the working class as private property'. [13]

\section{Capitalism}

Capitalism is an economic system (Free market enterprise) where the means of production and, thereby, the economy and the use of resources are controlled by individual business owners and companies. Once the capitalist has set up the production, all value is created by the labor involved in producing the product. A capitalist's profit comes from exploiting labor, i.e. from underpaying workers for the value that they are creating. Capitalist's sole aim to accumulate as much wealth even to the extent of increasing the price of the stock as the government plays a minor role.

Marx maintained that within the capitalist system, labor was a mere commodity that could gain only subsistence wages. He believed there are two major flaws in capitalism that lead to exploitation: the chaotic nature of the free market and surplus labor. Capitalists would force workers to spend more time on the job than was necessary to earn their subsistence and then appropriate the excess product, or surplus value, created by the workers. In simple words, the workers create value through their labor but are not properly compensated. Their hard work is exploited by the ruling class, who generate profit not by selling their products at a higher price but by also paying staff less than the value of their labor.

So, Capitalism is a system that makes the rich even richer by allowing individuals the opportunity to increase their personal financial growth. On the contrary, the workers would become poorer and poorer. A time comes when they experience alienation, i.e. the workers becoming more distanced from, or isolated from their work; resulting in them a feeling of powerlessness. This makes the Capitalists and the Working Class becoming two different classes as they have opposing interests that are separated by a wide gulf of wealth and power, making a Class Conflict inevitable [14]

So the Capitalists (Bourgeoisie) become an Exploiter (Oppressors) Class and he Workers-the Exploited (Oppressed) Class and there starts the Class Conflict.

Karl Marx was dead against capitalism and exploitation as he considered the free market system of capitalism not as a free system obeying rules of the game, but as a disordered interplay of blind forces that enslave humans. Marx said: 
Sehgal, M. L. (2020). Marxism, Communism, Marxian Socio-political Economic Theory and the Socialist World: Part-I. Advances in Social Sciences Research Journal, 7(5) 70-90.

"As the capitalistic institutions have been no more than a system of coercion serving to protect bourgeois ownership of the means of production, the insight of the individual reason should be used to smash them up (Marx, 1)".[15]

\section{Two Classes in Society}

A class implies a group of peoples (workers/ laborers) who share common economic interests; are conscious of those interests and engage in a collective action to advance those interests. In a way, the structure of the production process forms the basis of Marxian Class. The Class is the basis for power. Some classes are more powerful than others because they own more property and wealth, and this gives them the means to defend and keep what they hold. The Bourgeoisie forms the most powerful class as it owns the factors of production and the other is the working class that has to sell its labor to make a living. Ownership of the means of production enables the bourgeoisie to organize the industrial labor process and workers are driven to seek employment by the needs of their reproduction. The labor is compelled to enter an employment relation not by external compulsion, but by economic necessity. Once they enter the capitalist labor process, workers are remunerated with a wage, a monetary sum representing the "exchange value" with which the capitalist purchases the worker's labor power. The wage is expressed in terms of the duration of the working day and is calculated based on the goods that workers need to reproduce. Therefore, the wage does not recognize specific forms of labor or skills: it only compensates "abstract" labor power.

\section{Labor and Class Conflict [16]}

Marx argued that in capitalist society the bourgeoisie and proletariat are fundamentally opposed. Those who hold the view regard class conflict and socialist revolution as inevitable, regardless of what any single individual may do. Social change occurs as a result of class conflict; only the classes change. In the olden times, there was a conflict between the landed aristocracy and the rising bourgeoisie while in the capitalist society, the major conflict is between the bourgeoisie and the proletariat.

Marx says that that the class struggle is not only inherent in the system because of the tension between capitalists and workers but it intensifies over the time as the businesses eventually become larger and larger, due to the inherent efficiency of large outfits and their ability to withstand the cyclical crisis that plague the system. Ultimately, society moves to a two-class system of a few wealthy capitalists and a mass number of underpaid, underprivileged workers.

The capitalist spends money (M) and buys commodities (C). Through production (Mp) and labor power (Lp) and with the process of production $(\mathrm{P})$, he creates a product $\left(\mathrm{C}^{\prime}\right)$ whose value would exceed that of C. Finally, he sells and recovers money ( $\left.\mathrm{M}^{\prime}\right)$ more than $(\mathrm{M})$.

There comes a capitalist's lust for multiplying the profit and he reinvests but would not share this additional profit with the working class and, thus, the bourgeoisie and thus proletariat become fundamentally opposed in a capitalistic society. Marx believes that real wealth was only created by the labor power of the workers but the wages that are paid to them are well below that taken in profit by the people who own the factors of production and, thus, the contradiction. The capitalist plays another truant. The growing "concentration" of accumulated capital and, thereby, increasing his profits, he drives the other competitors out of the market. In this elimination of competition, the capitalist produces a centralization of ownership in several large companies. But successful 
competition also requires increasing investment in machinery ("constant capital"). As a result, the surplus value extracted from human labor is eroded, and, in the long term, the rate of profit for the CMP, as a whole, tends to fall. In the process, a large number of workers are expelled (laid off) from the production process which ends up swelling the unemployed, i.e. "relative surplus population". In conclusion, as the organic fixed capital requirements of production rise due to the advancements in production, generally, the rate of profit tends to fall.[17] The demands of the working class are ultimately incompatible with capitalist exploitative nature. The capitalists also try to establish a form of state whose laws and institutions protect private property, capital accumulation and curtail liberties that enable contractual relations between workers and capitalists to reproduce the "base" of capitalist relations of exploitation. Since the profits do not flow to the workers, they organize themselves collectively as they become conscious of their exploitation as a class. Therefore, they organize to accelerate capitalism's eventual demise and establish a socialist society where class domination is abolished. All this leads to the Labor and Class Conflict. Class struggle intensifies over time as businesses become larger and larger, due to the inherent efficiency of large outfits and their ability to withstand the cyclical crises that plague the system. Ultimately society moves to a twoclass system - a few wealthy capitalists and a mass of underpaid, underprivileged workers.

\section{Marx wrote: [18]}

"Thee specific economic form in which unpaid surplus labor of rulers and ruled...Upon this is founded the entire formation of the economic community which grows up out of the conditions of production itself, and this also determines its specific political shape. It is always the direct relation of the owners of the conditions of production to the direct producers which reveals the innermost secret, the hidden foundation of the entire social construction, and with it of the political form of the relations between sovereignty and dependence, in short, of the corresponding form of the state".

To do away this alienation, i.e., not being allowed to control their work, from this discredited Capitalism, Marx believed that Capitalism had to end and be replaced by a Socialist system that would make all equal and have all people's needs met.

\section{Socialism: Explained Briefly}

Karl Marx is called the father of socialism. He described socialism as:

\section{"A lower form of communism and held the opinion that socialism was an intermediary} step in moving from capitalism to communism". [19]

Socialism is an economic system that focuses on the betterment of the all; rather than the advancement of a few individuals as the means of production are owned collectively by the people and the state where everyone works and the rewards are distributed to all people by the government and, thus, no free-market system would exist and everyone becomes Proletarian (Wage earner- the economic and social class consisting of industrial workers who derive income solely from their labor) with the automatic end of Bourgeoisie with no Exploiter or the Exploited Class and there would end the Class Conflict. Since all the resources are provided by the government, people who earn more may have to pay somewhat higher taxes and may feel dissatisfied. Eventually, there would come a time where a communistic or socialist society would take over from capitalism. This will not be the result of a new force of production but will get rid of the contradictions. Collective production would remain but ownership would change altogether. Instead of the Bourgeoisie 
Sehgal, M. L. (2020). Marxism, Communism, Marxian Socio-political Economic Theory and the Socialist World: Part-I. Advances in Social Sciences Research Journal, 7(5) 70-90.

owning the production, it will be shared by all those who would share the wealth that their labor produces with no exploitation of any person.

Many movements across Europe embraced the Marxist view of socialism which led to the protests and uprisings of the working class, including the labor unions.

\section{Basis of Marx 'Theory of Economics}

Four points which make the basis of Marx 'Theory of Economics is:

1. Capitalist Mode of Production (CMP)

2. Labor Theory of Value (LTV)

3. Theory of Surplus Value(SV)

4. Diminishing (Falling) rate of profit

Rise of Labor forms the basis of Marx's Theory of Economics which are, very briefly, explained as follows with details to be discussed in Part-II.

\section{Capitalist Mode of Production (CMP) [20]}

Just as in biology, the 'cell' is the basic unit; similarly, Marx believed that every commodity is made from economic cells. The overall value of a commodity produced by a capitalist can be calculated from the total value of these basic cells. In a way, the capital spent by a capitalist is transformed by every-amplifying circular flow is labor-power. The system, thus, created by the capitalist can produce profits on average, i.e., the amount of capital can grow in general when the value of laborpower is less than the value of the commodity produced. In short, Capitalist Mode of Production (CMP) is defined as:

'The capitalist purchases labor-power and then creates a commodity.

\section{Labor Theory of Value (LTV) [21]}

It was an early attempt by economists to explain why goods were exchanged for certain relative prices on the market. The value of a commodity can be measured objectively by the average number of labor hours necessary to produce it. Although, LTV is usually associated with Marxian Economics this term was well accepted in the theories put forward by classical liberal economists It is believed that this economic doctrine was developed by the English Classical School of Thought of Economics by Adam Smith (1723-1790) and David Ricardo (1772-1823) well before Marx appeared on the scene. Marx adopted it in Toto in his 'Das Kapital'.

The most appropriate but meaningful explanation of this often-used term is given as follows:

The real price of everything, what everything costs to the man who wants to acquire it, is the toil and trouble of acquiring it. What everything is worth to the man who has acquired it, and who wants to dispose of it or exchange it for something else, is the toil and trouble which it can save to himself, and which it can impose upon other people. [21]

\section{Surplus Value [22]}

Capitalists create commodities whose values exceed workers' remunerations. They sell these commodities in the market 'realizing' their value. They appropriate the difference between the value of such goods and the value of the labor power used to produce them. Marx calls this difference the 'surplus value'. 
"Surplus value is equal to the new value created by workers above their labor-cost, which is appropriated by the capitalist as profit when products are sold".

The money that capitalists earn from realizing their 'surplus value' contains a profit, which capitalists reinvest to restart the productive cycle named 'extended reproduction of capital' which, for Marx, is the 'main cause of the 'exploitative nature' of capitalism. Here comes point of difference between Marx and capitalists as Marx believed that the origins of profit and surplus extraction in the very process of production are in no way be called Supply and Demand as propagated in the "bourgeois" political economy. This enabled him to give a logical account of the mechanism of economic exploitation under capitalism.

\section{Diminishing (Falling) Rate of Profit}

Marx believed that the advance of technology will increase efficiency and result in the increased productivity per unit of capital invested, i.e. organic composition of capital would decrease with the machine replacing the labour. Now assume if only the labor (man-power) were used to produce the new additional value, this greater physical output would have manifested a new value. But now a gradually decreasing surplus value(SV), relative to the value of production capital invested; ultimately had resulted in a decrease of an average rate of industrial profit.

Marx argued that this decrease in profit is not because the productivity is decreased; rather it has increased with the aid of a bigger investment in equipment and materials. [23] So The progress in technology has a long-term 'labor-saving bias'; with an overall effect of saving labour time in producing commodities had to be a falling rate of profit on production capital, quite regardless of market fluctuations or financial constructions. [24]

Their central idea of three - the (SV) was calculated by Marx by applying the LTV. Later on, he tried to correlate it with the Falling Rate of Profit. But many economists turned their backs from Marx's principle of calculating the SV. Some, even, opined that it is, rather, an uphill's task to calculate the exact SV.

\section{Economy: A Basis of Social, Religious and Political Views of a Society} Marx stated: [25]

"The economy, the material productive forces and the relations of people to the means of production are the basis that determines the political and juridical forms, morals, political, juristic, philosophical theories, and religious views".

Though Marx believed that political, economic, and social conditions of a working-class are all interwoven into one and other, yet he remained confined to locating economic phenomena within their wider social and historical context (Marx 1859, 20) as enunciated by The Materialist Theory of history as summarized by Marx as follows:

In the social production of their existence, men inevitably enter into definite relations, which are independent of their will, namely relations of production appropriate to a given stage in the development of their material forces of production. The totality of these relations of production constitutes the economic structure of society, the real foundation, on which arises a legal and political superstructure. The mode of production of material life conditions the general process of social, political,and intellectual life.[26] 
Sehgal, M. L. (2020). Marxism, Communism, Marxian Socio-political Economic Theory and the Socialist World: Part-I. Advances in Social Sciences Research Journal, 7(5) 70-90.

The development of the forces of production brings them into conflict with the relations of production, and these conflicts are reflected in 'class struggle'. Such conflicts are the basic motive principle of history. Their specific development within capitalism creates not only the economic conditions for revolutionary change but also its agents- the industrial working class. History is divided into distinct stages or modes of production. The capitalist mode of production is a transitory form, destined to be superseded by a higher socialist stage of society.

\section{The Big Three}

Many other economists of repute have advanced their theories or otherwise added to the body of knowledge in economics. But we will restrict ourselves only to two of the celebrated economists and their Economic Theories as Adam Smith and John Maynard Keynes. Smith, Keynes, and Marxtogether are called the 'The Big Three'Smith proposed his Economic Theory over a century before while Keynes propagated his economic ideas after over half a century during 'The Great Depression' period started in 1929 and lasted until the late 1930s after Marx has left the world (1887).

Adam Smith (a Scot; 5June1723-17July1790 ), Karl Marx(a German; 5 May 1818 -14 March 1883), and John Maynard Keynes later Lord Keynes(a British;05 Jun 1883 - 21 Apr 1946 ) are the three widely recognized and the most influential Economists, and are called 'The Big Three'. The Economic views of both Smith and Keynes were quite different from those of Karl Marx because the economic conditions in the word were altogether different during their era. Smith wrote his treatise in the form of his famous book entitled 'The Wealth of Nations' in1776 [27] when the United States got the independence while Keynes gave a shape of his economic views by publishing a book named 'General Theory of Employment, Interest, and Money' in1936; [28] the period when the whole world was reeling under adverse effects of 'The Great Depression'.

\section{Classical Economics of Smith}

laissez-faire (policy of leaving things to take their course, i.e. noninterfering attitude) by the government toward the marketplace will allow the "invisible hand" to guide everyone in their economic matters. Smith wrote in his widely read book, The Wealth of Nations' (1776) as follows: [27]

"The individuals in society, each acting in his or her self-interest, manage to produce and purchase the goods and services that they, as a society, require. He called the mechanism by which this self-regulation occurs"the invisible hand,"

Though he did not name the 'hand' but would explain this phenomenon in a beautiful was as follows:

A butcher, a baker, and candlestick maker individually go about their business. Each produces the amount of meat,bread, and candlesticks the judges to be correct. Each buysthe amount of meat, bread, and candlesticks that his household needs. And all of this happens without their consulting one anotheror without all the king's men telling them how much to produce. In other words, it's 'the free market economy' in action.

He was of the firm belief that the division of labor always helped: [29] 
It is the great multiplication of the productions of all the different arts, in consequence of the division of labour, which occasions, in a well-governed society, that universal opulence which extends itself to the lowest ranks of the people.

He cited his own experience when he happened to visit a pin-making factory and described the 18step process to make the pins which were split up as follows

One man draws out the wire. Another man straightens the wire. A third man cuts the wire, and so on. He observes that the process makes the factory more productive. He said that a factory of 10 workers could make 48,000 pins in a day. Every person in the factory would have to make about 4,800 pins a day. However, if they were working separately, Smith argues they would have made far fewer.

Smith believed that:

In general, if any branch of trade, or any division of labour, be advantageous to the public, the freer and more general the competition, it will always be the more so. "Competition between businesses was important as it couldensure fair prices and quality products. It could also drive innovation and satisfy consumer demand. Moreover, competitionkeeps everyone honest. If you don't like one business, you can always go to another one instead".[30]

\section{Keynes' Economic Theory (Keynesian Economics)}

According to Keynes:

"To keep the economy stable and growing, it is desirableto use the government's power to spend, tax, and borrow. In other words, to boost up a sluggish economy, the government must pump up spending".[31]

During this time of 'The Great Depression', Keynes wrote that the only way out to come out of the recession in the economy was that the government to start spending to put money into the private sector and get demand for goods and services up and running again. President Franklin D. Roosevelt agreed with Keynes' views and tried it in $1930-1940$.

Keynes, page No: It was called a different type of 'Capitalism' where the government's resources were utilized by Capitalists who,in turn, would help the government in generating employments.[32]

A massive public works program was started. But soon the United States jumped into the WW-II. The war efforts boosted production such as making of various types of weapons, ammunition road vehicles, and planes. Moreover, millions of men were employed by the army.

\section{Comparison of Economic Theories of 'The Big Three'}

In the world of economics Smith, Marx and Keynes are called Big Three in Economics

Adam Smith talked of the 'invisible hand' concept and vision of rich and poor flourishing together under laissez-faire and an unfettered market. Karl Marx called capitalism exploitation of the underprivileged and challenged it even by using violent revolution which appealed to workers and intellectuals throughout the world while Keynes suggested activist government policies to be an ideal solution to the 'Great Depression' a remedy a crisis-prone market system. 
Sehgal, M. L. (2020). Marxism, Communism, Marxian Socio-political Economic Theory and the Socialist World: Part-I. Advances in Social Sciences Research Journal, 7(5) 70-90.

The question 'whether all economic theories were equally valid' is very difficult because 'The Big Three' applied their respective economic ideas in three different eras when the economic conditions of the world, especially in the countries where the three celebrated worked, were altogether different. Accordingly, when extrapolated for other countries, their citizens also benefitted immensely. It is rightly said by Daniel Adler [33]

As society moves about the ordinary business of life, economics always hums along in the background; it is observed by some, influenced by others, yet it affects everybody.

The power of economics lies in its ability to reveal the complex workings of society. A detailed argument on the relative importance of the three theories is given as follows:

'Economically, they shared similar goals-have one thing common, i.e, they wanted to increase the standard of living of the citizens and for the good of the government but emphasize different areas based on the diversified understanding of the human nature, duty of the government and operation of the market, interaction among the government, market, and people in which different countries adopt different ideologies for the good of the peoples. They have varied ideas on how to construct an ideal society by different roles of the various stakeholders and as a result, revealing the demand and the need of the society of their era'. [34]

But the following instances which may be treated as exceptions tend to prove that the pendulum looks to tilt toward capitalism:

- No doubt, some Keynesian policies gave mixed results but the overall picture seemed to confirm Keynes's arguments. Until the 1970s, Keynesian thought dominated American economics. The 1980s and 1990s saw a return to economic theories that went back to Adam Smith. The "Great Recession" of the 2000s, especially of 2008 has presented a new opportunity to debate Keynes's ideas.

- Even Karl Marx saw capitalism as a necessary stage for building a society's standard of living but felt that workers would become unhappy under capitalism.

The capitalist countries, by applying Smith's idea of competition, would drive more innovation because of their affluence to purchase machinery. They generate new ways to attract customers who could purchase their goods among other competitors which, in turn, drives further innovation in an attempt to stay competitive. It is not possible in communist countries where all goods would be equally shared and distributed. So no one would feel the need to compete for customers; leading to stagnation without innovation.

But the lack of competition may not be treated as a rule of the economics as two Communist Majorsthe Soviet Union and China have made the most rapid economic developments and are fairly at par with the western countries. All said, the following paragraph which, indeed, is a quote from Keynes may, well, be cited to answer the best of three theories:

The ideas of economists and political philosophers, both when they are right and when they are wrong, are more powerful than is commonly understood. Indeed the world is ruled by little else.Practical men, who believe themselves to be quite exempt from any intellectual influences are usually the slaves of some defunct economist. Madmen in 
authority, who hear voices in the air, are distilling their frenzy from some academic scribbler of a few years back'.[35]

\section{Marxian Theory of Economics: An introspection}

Although everyone appreciates the noble principles of economic equality, the welfare of the poor, and the emancipation of masses, yet it is baffling as to why has Capitalism remained durable and survived; rather flourished, especially, in the West where it has survived for over two centuries. Marx would explain it in two ways:

1. The ruling elite has monopolized political power, the laws, and other institutions to maintain their control. They legitimized their power and, thus, have managed to hide from the people the true nature of their exploitation by propagating the ideas of equality and freedom, i.e. would proclaim that the relationship between worker and owner of the factories as an equal exchange.

2. The work-force is not that enlightened that they could see their exploitation as just, natural, and proper. Marx calls this a false consciousness of reality. [36]

\section{Capitalism Overweighs Socialism}

But look at the anti-climax. Although Marx was born and initiated his revolutionary economic ideas in Germany and, then, had to migrate to England to complete his exalted socio-economic thought, yet neither of the two industrial giants of their times turned socialists; meaning, thereby, that the labor class, though highly enlightened, preferred to stay with Capitalism rather than to go with the Socialistic pattern; forget the Communism.

The demise of the former communist USSR, the unification of East and West Germanys after over four and a half decades, socialist countries like North Vietnams (now North and South Vietnams are united as the Socialist Republic of Vietnam on 2 July 1976 ), as well as the ever warring,North and South Koreas( united till the end of WW-II in 1945 as Korea), Cuba and Venezuela,etc,is an eyeopener for the Marxists.

The list will become longer if we include Poland, Czechoslovakia, Hungry, and China. But they have not included here the first three countries had no histories of being divided or united by the then super-powers; China, being an iron-walled country practicing Maoism, which does not fall under the ambit of Communism as practiced by Marx or its modern face- the Leninism.

\section{Comparison of Economies of East and West Germany}

East and West Germanys which constituted a single country (Germany) up to the end of WW-II (1939-45); was split as per 'The Potsdam Agreement', the Berlin Declaration of 5 June 1945 and adopted on August I, 1945 agreement between three of the Allies of WW-II, the United Kingdom, the United States, and the Soviet Union. It concerned the military occupation and reconstruction of Germany; its borders were split into four zones; two of them being called East and West Germany. East Germany came under the control of the USSR and adopted the Socialistic pattern while theWest Germany adopted for an open economy. But the wisdom dawned and two Germanys, the East, and West were reunited as one country by demolishing the dividing Berlin Wall in 1991; now called German Democratic Republic (GDR) in1991. 
Sehgal, M. L. (2020). Marxism, Communism, Marxian Socio-political Economic Theory and the Socialist World: Part-I. Advances in Social Sciences Research Journal, 7(5) 70-90.

We try to explain this point by comparing their GDPs during the years they would exist as two separate countries. The GDP (gross domestic product) measures the national income and output for a given country's economy and is equal to the total expenditures for all final goods and services produced within the country in a stipulated period. East and West Germany which constituted a single country (Germany) up to the end of WW-II(45); was split [37] The eastern part of Germany was richer than the western part before World War II. The entire country's economy was then destroyed during WW-II. The difference between socialism and free enterprise can be well demonstrated by the economies of the two Germanys as follows: [38]

Before 1945, the East German economy had per capita national income $103 \%$ of West Germany, compared to a mere $31 \%$ in 1991 . So here is the case of an economy that was relatively wealthy, but lost out in a relatively short time. The economic conditions in West Germany and East Germany diverged dramatically because it had a good policy and was placed in the top 10 economies between 1950 and 1975 while East Germany suffered from socialism as is illustrated by comparing their GDP values as given in the Tables: 1,2 and $3[39,40,41]$

\section{Comparison of North and South Vietnam Economies}

The difference between the GDP of North and South Vietnam can be explained by the two different forms of governments. The Republic of Vietnam (South Vietnam) had an open market economy and the Democratic Republic of Vietnam (North Vietnam) became a communist country up till both were united in 1975 when the Vietnam War ended. The Tables: 4 and 5 give data regarding the difference in the GDPs of North and South Vietnams (1956-1975); during the years they were two separate countries. $[42,43]$.

\section{Comparison of South Korea and North Korea Economies}

The same story is repeated in South Korea, an open economy, and North Korea, a communist country. Table: 6 gives data regarding the difference in the GDP growth rate of North and South Korea (1990-2017) which amply coveys that politics and Type of Government are the major contributors to the economic health of a country. [44,] The Table: 7 gives data give the GDP Per Capita of South Korea (2008-19)[45]

Graphical representation of GDP per capita (USD) of North and North Korea (1950-2008) is represented in Fig.1: [46]

The GDP values of North Korea and South Korea represent $\quad 0.01 \%$ and $1.39 \%$ of the world economy [ Source: The World Bank and projections from Trading Economics

\section{Post-Soviet Union Russian Economy [47]}

The dissolution of the USSR on 26 December 1991(legally ceased to exist on 31 December 1991) was initiated way back by Boris Yeltsin, the first elected president in June 1991. He began implementing many radical economic reforms including liberalization and mass privatization from a centrally-planned socialist economic system where production and distribution of goods were centralized and directed by the government. So Modern Russia has a capitalist mixed - economy in which is the mixture of the private sector and the public sector. Like most of the other members of the former USSR, Russia also witnessed a state of serious disorder and economic chaos at the time of independence. 
By mid-1994, 70\% of the economy was privatized by Boris Yeltsin. It was continued by his successor Vladimir Putin after failing health forced Yeltsin to withdraw. Putin had to face several teething problems like the stabilization of the ruble, building a strong and vibrant economy; especially when remnants of an old structure continued to haunt the present and the crunch of the natural resources in the Post- dissolved Russia. So the economy performed badly and during 1991-1998, Russia lost nearly $30 \%$ of its real GDP. But a significantly depreciated ruble helped stimulate domestic production leading to a spurt of economic growth with real GDP growth reaching 8.3\% in 2000. Between2000-2002, Putin ordered several economic reforms like tax reduction, ease of doing business, and the privatization of agricultural land. So much so, the 1999-2008 periods turned out to be a Period of Rapid Growth for the newly created Russia. The per capita GDP showed an appreciable upward trend; though two dragging factors would continue to haunt the new Russia for years to come as follows:

Politically Russia competes well with the USA due to its size, natural resources, population, and the strong military. But what to talk of GDP of the USA, Russia is even behind the pre-split USSR. This bitter reality lies in the fact that the post-split Russia has lost two very important stimulants

1. There was a crunch in natural resources especially the financially most promising sectors like Oil, natural gas, coal, iron ore, timber, gold, manganese, lead, zinc, nickel, mercury, potash, phosphates, and most strategic minerals which were lost other states of the pre-split USSR.[48]

2. The vast decline in the area, i.e. from 17,125 million square kilometers to 22.4 million square kilometers which included one-sixth of the Earth's land surface. $[49,50]$ But the new Russia can console itself in the sense that now it has higher per capita GDP than the USSR.

Although, it looks like perplexing statics, yet can be explained as follows:

- Relative to decrease in area, the population of the new Russia has decreased all the more i.e. the USSR had 286,730,819 (1989) and the new Russia has 145.93 million inhabitants (2020).

- The loss from Agricultural Economy in the new Russia is more than compensated by more production of oil which up till recently had much higher appreciated value than in1991,i.e. pre-split USSR. [51]

\section{Cuba: Failed by Socialism}

Cuba has been governed by a Communist dictatorship for over sixty years and is synchronized with Field Castro, the oldest Communist Giant, who challenged the U.S. might, single-handedly but sadly is failed by Socialism nee Communism. It has fully demonstrated the weaknesses of communism

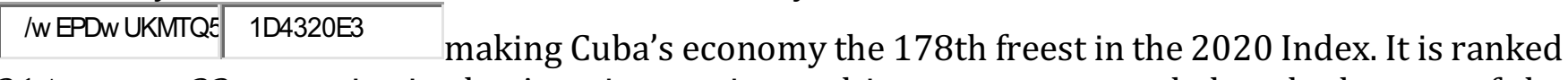
$31^{\text {st }}$ among 32 countries in the Americas region and its economy regarded at the bottom of the repressed category with modest GDP growth. It is neither a member of the World Bank nor is included in the World Bank's 2019 Doing Business report. The state controls the formal labor market but has opened some retail services to what it calls self-employment. New U.S. sanctions in 2019 and the economic collapse of Venezuela, which had been providing Cuba with billions in energy subsidies, have forced the widespread rationing of goods. Table: 8 gives an idea of its GDP from 1970-2019[52] which represents $0.08 \%$ of the world economy and averaged 37.98 USD Billion from 1970 until 2019, and a record low of 5.69 USD Billion in 1970.[53] 
Sehgal, M. L. (2020). Marxism, Communism, Marxian Socio-political Economic Theory and the Socialist World: Part-I. Advances in Social Sciences Research Journal, 7(5) 70-90.

\section{Per Capita GDP of Cuba}

Very low values of Per Capita GDP will make Cuba's economic mess all the more clear and is represented in Table: 9[53]

\section{Venezuela: A Victim of Mixed Economy}

The political system, after years of erosion, has become a hybrid of democratic and authoritarian features - a highly unstable mix.[54] Venezuela, the sixth-largest member of OPEC nation, which, once, boasted of having the highest standard of living in Latin America, has, now, been plunged into hyperinflation, which by November 2019 stood at 35.8\%. Venezuela's economy is facing its worst crisis in recent history and has experienced hyperinflation since 2015, far exceeding the oil price collapse of the 1990s. Its economic misery started during the 1980s with the collapse of oil prices. The currency started to experience progressive devaluation and inflation reached peaks of $84 \%$ in 1989 and 99\% in 1996. Venezuela, now, occupies the bottom position of the list of economic projections of 32 Latin American countries (together called Americas); even beating Argentina in terms of the worst economic scenario. By 2020, the Venezuelan economy will contract 10\%. [55] The contraction of Venezuela's GDP next year will be $14 \%$ and at the end of this year is projected to be $-25.5 \% .[56]$

The economy of Venezuela is a market-based mixed economy based largely on the petroleum and manufacturing sectors; Oil comprising 95\% of Venezuela's exports and 25\% of its GDP.[57]So high prices of oil provide a boon to the country's economy. From 2006 until mid2014, (excepting world recession in late 2008), the oil prices hovered around \$100- \$125 per barrel and the revenue boost enabled Venezuela to fund its budget and wield political power by provided subsidized oil to as many as 13 neighboring Latin American countries.

The worst started in1999.Inflation accelerated to $700 \%$. The Government implemented a series of redistributive policies aimed at alleviating poverty to reduce inequality at the expense of the overall economy. But all went in vain as the redistribution policies depended completely on revenue from Venezuela's state-owned oil industry. The private industry was strangled by centrally planned price controls, which caused widespread shortages of basic goods. Socialistic radicalism did not pay and the President had to switch over to [57]

"neither for savage capitalism, nor socialism, nor Communism". Instead, he claimed to support a "third way" ---- a balance between socialism and capitalism.

The factors such as Hyperinflation, low crude oil production due to the sanctions imposed by the United States, migration of 4.7 million Venezuelans due to the rise in unemployment has lowered the growth. Even an increase in the minimum wage did not make a difference and have not proved effective in mitigating the economic crisis as follows:

In January 2019 , the minimum wage was 18,000 sovereign bolivars which were increased in April to 40,000 , plus 25,000 food basket and appreciated minimum by $375 \%$ to 150,000 , plus a food allowance of 150,000 , which was equivalent to about US $\$ 15$ at the time, but today stands at US $\$ 6.48$ due to the devaluation of the currency against the US dollar. By 2020 Venezuela will be the country with the highest unemployment rate at 50.5\%, which is 3.3\% points higher than expected for 2019 (47.2\%).[58] GDP in Venezuela was worth 280 billion US dollars in 2019, $(0.23 \%$ of the world economy), and its economy will continue to be the last in all of Latin America and the Caribbean.[59] 


\section{GDP per capita of Venezuela}

A graphical representation of Per Capita GDP of Venezuela is given in Table. 10.[60]

Venezuela, which was once the richest and the most stable democracy in Latin America went on the brink of collapse when it opted for dictatorship. Venezuela's paradox is:

"that the government is too authoritarian to coexist with democratic institutions but too weak to abolish them without risking collapse.[61]

\section{The Interdependence of Cuba and Venezuela}

There exist some agreements whereby Venezuela provides cheap oil in exchange for Cuban "missions" of doctors to bolster the Venezuelan health care system. As of 2015 records, Cuba had the third-highest number of physicians per capita worldwide (behind Monaco and Qatar)[62] Cuba also sends a large number of doctors to other countries as aid, as well as to obtain favorable trade terms.[63] The Venezuelan subsidy is higher than whatever subsidy the Soviet Union gave to Cuba,[64] with the Cuban state receiving cheap oil and the Cuban economy receiving around \$6 billion annually. According to Mesa-Lago, a Cuban-born US economist:

"If this help stops, the industry is paralyzed, transportation is paralyzed and you'll see the effects in everything from electricity to sugar mills, ".[65]

Cuba depends on Venezuela more than Venezuela does on Cuba. According to 2012 reports, Venezuela accounted for $20.8 \%$ of Cuba's GDP while Cuba only accounted for about $4 \%$ of Venezuela's.[66]. That is why, the inflation is nearing $800 \%$ and the GDP of Venezuela is declining by $19 \%$ in 2016; depriving Cuba of the amount of payment and the heavily subsidized oil. Further budget cuts are in the plans for 2018 marking a third straight year.[67]

\section{CONCLUSION}

We should ponder as to why the adoption of liberalization, privatization and competitive systems by the former communist regimes (Communism is a form of government that falls on the socialism spectrum) have improved their market economies to quite an appreciable extent. This reflects the importance and value of capitalism; courtesy- some limitations of Marx's Economic Theory, which will be taken up in Part-II.

\section{References}

[1].Marx 1844: Economic and Philosophic Manuscripts of 1844 (also referred to as The Paris Manuscripts)

[2].Marx 1867-94: “Marx on Absolute and Relative Wages and the Modern Theory of Distribution”, pp.40-41 by Enrico Sergio Levrero-Dipartimento di Economia, Università degli Studi Roma Tre, Italy)

[3]. Marx 1905-10: Socialism and Internationalism- Social Democrat, 1905, Vol. 9. no. 10, 15 Oct 1905, p.607; Transcribed: by Ted Crawford) wherein he bared the economic laws of the modern [capitalist] society

[4]. Marx 1867-94 Vol.1,p. 10- Capital: A critique of political economy).

[5]. (Marx 1844, 1845, 1857-8- Marx \& Engels Collected Works Vol 04, Marx and Engels: 1844-1845 by Karl Marx, Frederick Engels

[6].Engels to C. Schmidt, 5 Aug 1890

[7]-Marx-1: Labor and Class Conflict

[8]Paul Lafargue (15 January 1842-26 November 1911), the younger son-in-law of Karl Max, was a French revolutionary Marxist socialist journalist, literary critic, political writer, and activist His best- known work is The 'Right To Be Lazy'. At the age of 69, he and 66-year-old wife Laura died together by a suicide pact

[9]-Marx to Lafargue: 'Ce qu'il y a de certain c'est que moi, je ne suis pas Marxiste.'"

- Letter to Bernstein, 1882. 
Sehgal, M. L. (2020). Marxism, Communism, Marxian Socio-political Economic Theory and the Socialist World: Part-I. Advances in Social Sciences Research Journal, 7(5) 70-90.

[10]Manale, M. (1974) Aux Origines du concept de marxism. In Economies et société, Cahier del'ISMEA, Series 5, No. 17

[11].International Encyclopedia of the of the Social Sciences

[12] From Wikipedia and Dictionary meaning of Communism

[13].As given in the first volume of Capital (1867) and by' The Free Dictionary'

[14]John Macionois (1916), “Society: The Basics', 14th Edn, Publisher: Pearson

[15]. Marx, 1

[16]. Marx Part 1

[17]. It is explained in Part-III of Das Kapital- Volume III subtitled as 'The Process of Capitalist Production as a Whole' which was prepared by Friedrich Engels from the notes left by Karl Marx and published in 1894.

[18]. Marx's Theory of Working-Class Revolution

[19]. Marx definition of socialism

[20]."Capitalist Mode of Production," ' International Encyclopedia of the Social Sciences', Retrieved on 09 January 2020

[21]. Adam Smith (1776), "The Wealth of Nations", Book:1, Chapter: 5, Amazon

[22]."Surplus value" is a translation of the German word "Mehrwert", which means 'value-added' (sales revenue less the cost of materials used up), and is cognate to English "more worth"

[23].Friedrich Engels (1967; Orig. Edn1894) Karl Marx, Capital, Vol.3; New York: International Publishers, Chapter 2, 'The Rate of Profit', and Chapter 13,' The Law as Such.' John Weeks, 'Capital and Exploitation'., Chapter 8. Princeton University Press, 1980.

[24].Ernest Mandel "Economics", in David McLellan (Ed.), Marx - the First 100 Years. Fontana,1983. $\underline{\mathbf{C}}$

[25]. International Encyclopedia of the Social Sciences

[26].Marx1859, 20-1.

[27]. Adam Smith (1776), "The Wealth of Nations", Book IV, Chapter V, Digression on the Corn Trade, p. 540, para. b 43; Amazon

[28] John Maynard Keynes later Lord Keynes (1936), "General Theory of Employment, Interest, and Money”, Amazon [29]. Adam Smith (1776), "The Wealth of Nations", Book I, Chapter I, p. 22, para. 10, Amazon

[30]. Adam Smith (1776), “The Wealth Of Nations”, Book II, Chapter II, p.329, para. 106

[31]. John Maynard Keynes later Lord Keynes (1936), “General Theory of Employment, Interest, and Money”, Amazon [32]. Ibid

[33]. Daniel Adler, 'The Three Great Thinkers Who Changed Economic', Big History Project, adapted by News Ela staff on 07.30 .16

[34] Government and Economy (POL2106)

[35].A quote from Keynes- Chapter 24 of 'The General Theory of Employment, Interest, and Money'(1936), Amazon

[36].Ashley Crossman, “Understanding Karl Marx's Class Consciousness and False Consciousness," 'Thought Co', 25 July 2019

[37]. The 'Potsdam Agreement, called the Berlin Declaration of 5 June 1945 and adopted on August I, 1945 agreement between three of the Allies of WW-II, the United Kingdom, the United States, and the Soviet Union. It concerned the military occupation and reconstruction of Germany; its borders were split into four zones.

[38].Jaap Sliefer (2016), "Planning Ahead and Falling Behind”, Ist Edn, (German); Amazon

URL: http://dx.doi.org/10.14738/assrj.75.8178 
[39]. Maddison, Angus (2006), "Development Centre Studies.The World Economy,” Vol.1, A Millennial Perspective, MIT Press,p.406

[40]. Sleifer Jaap (2006), 'Chapter 3: East Germany GDP', “Planning Ahead and Falling Behind”, The East German Economy in Comparison with West Germany 1936-2002, p.50

[41]. Sleifer Jaap (2006), 'Chapter 3.3: 'High Growth of an Underachieve? : East Germany GDP', “ Planning Ahead and Falling Behind”, The East German Economy in Comparison with West Germany 1936-2002, p.66

[42].Economic growth around the world from ancient times to the present day: Statistical Tables, Phần 1. A.G. Vinogradov. WP IPGEB. P. 88-89

[43].Fledgling Financial Markets in Vietnam's Transition Economy, 1986-2003. Vuong Quan Hoang. P.5

[44].Published by Won So Jul 1, 2019

[45].IMF World Economic Outlook Database

[46]. Ibid

[47]. 'Transition from Communism to Capitalism' (1991-1998) By Matthew Johnston Updated 25 June 2019

[48]. An excerpt from the article 'Public domain material from the Library of Congress Country Studies', website http://lcweb2.loc.gov/frd/cs/. - Soviet Union

[49]. "Union of Soviet Socialist Republic", www.history-world.org. Archived from the original on 02-10.2012 Retrieved 23-09-2008

[50]. “Union of Soviet Socialist Republic”, Encyclopedia Britannica. Retrieved 20-8-2008

[51]. Wikipedia: Agriculture in Russia

[52].Source: World Bank

[53]. Trading Economics global macro models and analysts expectations \& The Word Bank

[54] How socialism turned Venezuela from the wealthiest country in South America into an economic basket case by Maxim Lott Published in Socialism 26 January 2019

[55].The IMF projection

[56].ECLAC prediction

[57]. Wikipedia: Economy of Venezuela

[58]. The IMF prediction in its World Economic Outlook report for 2020 regarding Venezuela

According to the World Bank and projections from Trading Economics

[59].

[60]. Published by H. Plecher, 26 November 2019 ( Data from the graph)

[61]. According to Steven Levitsky, a Harvard University political scientist

[62] Organization, World Health. (2015).World Health Statistics 2015. W. H. O.

[63]Tamayo, Juan O., “How will the Venezuela-Cuba link fare after Chavez’s death? Retrieved 6 March 2016

[64] Jeremy Morgan. “Venezuela’s Chavez fills \$ 9.4 billion yearly post-Soviet gaps in Cuba’s accounts. Latin American Herald Tribune. Retrieved 6 March 2016

[65] "As Hugo Chavez fights for life, Cuba fears for its future”, Telegraph. Co.uk.. Telegraph.co.uk. Retrieved 6 March 2016

[66] Piccone, Ted and Harold Trinkunas "The Cuba-Venezuela Alliance: The Beginning of the End?" Latin America Initiative on Foreign Policy at Brookings (2014): 1-12.

[67] Frank, Marc. "Cuba warns of further belt-tightening as Venezuelan crisis deepens." Reuters. N.p., 28 April 2017. 
Sehgal, M. L. (2020). Marxism, Communism, Marxian Socio-political Economic Theory and the Socialist World: Part-I. Advances in Social Sciences Research Journal, 7(5) 70-90.

\section{LIST OF TABLES: (1-9)}

Table: 1. Real GDP of East and West Germany (\$ million) [39]

\begin{tabular}{|l|l|l|l|}
\hline Year & $\mathbf{1 9 5 0}$ & $\mathbf{1 9 7 3}$ & $\mathbf{1 9 9 0}$ \\
\hline East Germany & 51,412 & 129,969 & $52,732(1989)[40]$ \\
\hline West Germany & 213,942 & 814,786 & $1,182,261$ \\
\hline
\end{tabular}

Table: 2.Growth in GDP Per Capita of East and West Germany (\$)

\begin{tabular}{|l|l|l|l|}
\hline Year & $\mathbf{1 9 5 0}$ & $\mathbf{1 9 7 3}$ & $\mathbf{1 9 9 0}$ \\
\hline East Germany & 2,795 & 7654 & $9,193(1989)[40]$ \\
\hline West Germany & 4280 & 13,147 & 18690 \\
\hline
\end{tabular}

Table: 3. Growth in GDP Per Capita in East and West Germany[41]

\begin{tabular}{|l|l|l|l|l|l|l|}
\hline Year & $\mathbf{1 9 4 5 - 5 0}$ & $\mathbf{1 9 5 0 - 6 0}$ & $\mathbf{1 9 6 0 - 7 0}$ & $\mathbf{1 9 7 0 - 8 0}$ & $\mathbf{1 9 8 0 - 8 9}$ & $\begin{array}{l}\text { Total:1950- } \\
\mathbf{8 9}\end{array}$ \\
\hline East Germany & 6.2 & 6.7 & 2.7 & 2.6 & 0.3 & 3.1 \\
\hline West Germany & 10.9 & 8.0 & 4,4 & 2.8 & 1.9 & 4.3 \\
\hline
\end{tabular}

Table: 4. GDP of North and South Vietnam (billion USD, 2015 price) [42, 43]

\begin{tabular}{|l|l|l|l|l|l|l|l|l|l|l|l|}
\hline Year & $\mathbf{1 9 5 6}$ & $\mathbf{1 9 5 8}$ & $\mathbf{1 9 6 0}$ & $\mathbf{1 9 6 3}$ & $\mathbf{1 9 6 5}$ & $\mathbf{1 9 6 7}$ & $\mathbf{1 9 6 8}$ & $\mathbf{1 9 7 0}$ & $\mathbf{1 9 7 2}$ & $\mathbf{1 9 7 3}$ & $\mathbf{1 9 7 4}$ \\
\hline $\begin{array}{l}\text { South } \\
\text { Vietnam }\end{array}$ & 11.28 & 12.7 & 15.27 & 16.42 & 13.52 & - & - & 10.917 & 9.142 & 10.030 & 10.285 \\
\hline $\begin{array}{l}\text { North } \\
\text { Vietnam }\end{array}$ & 2.587 & - & 4.113 & 4.70 & 6.00 & 6.41 & 6.98 & 10.689 & 11.31 & 11.145 & 11.422 \\
\hline
\end{tabular}

Table: 5. GDP Per Capita of North and South Vietnam (USD) $[42,43]$

\begin{tabular}{|l|l|l|l|l|l|l|l|l|l|l|}
\hline Year & $\mathbf{1 9 5 6}$ & $\mathbf{1 9 5 8}$ & $\mathbf{1 9 6 0}$ & $\mathbf{1 9 6 2}$ & $\mathbf{1 9 6 4}$ & $\mathbf{1 9 6 6}$ & $\mathbf{1 9 6 8}$ & $\mathbf{1 9 7 0}$ & $\mathbf{1 9 7 2}$ & $\mathbf{1 9 7 4}$ \\
\hline South Vietnam & 62 & 88 & 105 & 100 & 118 & 100 & 85 & 81 & 90 & 70 \\
\hline North Vietnam & 40 & 50 & 51 & 68 & 59 & 60 & 55 & 60 & 60 & 65 \\
\hline
\end{tabular}

Table: 6. Comparison of GDP growth rate (\%) of South and North Koreas [44]

\begin{tabular}{|l|l|l|l|l|l|l|l|l|l|l|l|l|}
\hline Year & $\mathbf{1 9 9 0}$ & $\mathbf{1 9 9 5}$ & $\mathbf{1 9 9 9}$ & $\mathbf{2 0 0 5}$ & $\mathbf{2 0 1 0}$ & $\mathbf{2 0 1 1}$ & $\mathbf{2 0 1 2}$ & $\mathbf{2 0 1 3}$ & $\mathbf{2 0 1 4}$ & $\mathbf{2 0 1 5}$ & $\mathbf{2 0 1 6}$ & $\mathbf{2 0 1 7}$ \\
\hline South Korea & 9.9 & 8.9 & 10.7 & 3.9 & 6.5 & 3.7 & 2.3 & 2.9 & 3.3 & 2.8 & 2.9 & 3.1 \\
\hline North Korea & -4.3 & -4.4 & 6.1 & 3.8 & -0.5 & 0.8 & 1.3 & 1.1 & 1.0 & -1.1 & -3.9 & -3.5 \\
\hline
\end{tabular}

Table: 7. GDP Per Capita of South Korea (2008-19) [45]

\begin{tabular}{|l|l|l|l|l|l|l|l|l|l|l|l|}
\hline 2008 & 2009 & 2010 & 2011 & 2012 & 2013 & 2014 & 2015 & 2016 & 2017 & 2018 & 2019 \\
\hline $\begin{array}{l}219339 . \\
9\end{array}$ & 19151.8 & $\begin{array}{l}23083 . \\
3\end{array}$ & $\begin{array}{l}25100 . \\
4\end{array}$ & $\begin{array}{l}25457 . \\
5\end{array}$ & $\begin{array}{l}27178 . \\
1\end{array}$ & $\begin{array}{l}29242 . \\
4\end{array}$ & $\begin{array}{l}28723 . \\
8\end{array}$ & $\begin{array}{l}29287 . \\
3\end{array}$ & 31605.2 & $\begin{array}{l}33346 . \\
3\end{array}$ & $\begin{array}{l}31754 . \\
0\end{array}$ \\
\hline
\end{tabular}


Table: 8. GDP of Cuba (unit: billion USD, 2015 price)[52]

\begin{tabular}{|l|l|l|l|l|l|l|l|l|l|l|l|}
\hline $\mathbf{1 9 7 0}$ & $\mathbf{1 9 7 1}$ & $\mathbf{1 9 7 2}$ & $\mathbf{1 9 7 3}$ & $\mathbf{1 9 7 4}$ & $\mathbf{1 9 7 5}$ & $\mathbf{1 9 7 6}$ & $\mathbf{1 9 7 7}$ & $\mathbf{1 9 7 8}$ & $\mathbf{1 9 7 9}$ & $\mathbf{1 9 8 0}$ & $\mathbf{1 9 8 1}$ \\
\hline 5.693 & 6.915 & 8.135 & 9.998 & 11.406 & 13.127 & 13.79 & 14.206 & 17.845 & 19.594 & 19.913 & 20.15 \\
\hline $\mathbf{1 9 8 2}$ & $\mathbf{1 9 8 3}$ & $\mathbf{1 9 8 4}$ & $\mathbf{1 9 8 5}$ & $\mathbf{1 9 8 6}$ & $\mathbf{1 9 8 7}$ & $\mathbf{1 9 8 8}$ & $\mathbf{1 9 8 9}$ & $\mathbf{1 9 9 0}$ & $\mathbf{1 9 9 1}$ & $\mathbf{1 9 9 2}$ & $\mathbf{1 9 9 3}$ \\
\hline 20.954 & 22.205 & 24.039 & 20.92 & 24.227 & 25.211 & 27.459 & 27.023 & 28.645 & 24.317 & 22.086 & 22.367 \\
\hline $\mathbf{1 9 9 4}$ & $\mathbf{1 9 9 5}$ & $\mathbf{1 9 9 6}$ & $\mathbf{1 9 9 7}$ & $\mathbf{1 9 9 8}$ & $\mathbf{1 9 9 9}$ & $\mathbf{2 0 0 0}$ & $\mathbf{2 0 0 1}$ & $\mathbf{2 0 0 2}$ & $\mathbf{2 0 0 3}$ & $\mathbf{2 0 0 4}$ & $\mathbf{2 0 0 5}$ \\
\hline 28.448 & 30.43 & 25.017 & 25.366 & 25.736 & 28.365 & 30.565 & 31.682 & 33.59 & 35.901 & 38.203 & 42.644 \\
\hline $\mathbf{2 0 0 6}$ & $\mathbf{2 0 0 7}$ & $\mathbf{2 0 0 8}$ & $\mathbf{2 0 0 9}$ & $\mathbf{2 0 1 0}$ & $\mathbf{2 0 1 1}$ & $\mathbf{2 0 1 2}$ & $\mathbf{2 0 1 3}$ & $\mathbf{2 0 1 4}$ & $\mathbf{2 0 1 5}$ & $\mathbf{2 0 1 6}$ & $\mathbf{2 0 1 7}$ \\
\hline 52.743 & 58.604 & 60.806 & 62.08 & 64.328 & 68.99 & 73.141 & 77.148 & 80.656 & 87.133 & 91037 & 96.851 \\
\hline
\end{tabular}

100.02 (2018); 99.0 (2020);101.0 (2021) and 103.00 (2022)

Table: 9. Per Capita GDP of Cuba from 1970- 2019 (unit: USD) [52]

\begin{tabular}{|l|l|l|l|l|l|l|l|l|l|l|l|}
\hline $\mathbf{1 9 7 0}$ & $\mathbf{1 9 7 1}$ & $\mathbf{1 9 7 2}$ & $\mathbf{1 9 7 3}$ & $\mathbf{1 9 7 4}$ & $\mathbf{1 9 7 5}$ & $\mathbf{1 9 7 6}$ & $\mathbf{1 9 7 7}$ & $\mathbf{1 9 7 8}$ & $\mathbf{1 9 7 9}$ & $\mathbf{1 9 8 0}$ & $\mathbf{1 9 8 1}$ \\
\hline 653 & $\mathbf{7 8 0}$ & 901 & 1088 & 1224 & 1379 & 1443 & 1473 & 1835 & 2000 & 2022 & 2036 \\
\hline $\mathbf{1 9 8 2}$ & $\mathbf{1 9 8 3}$ & $\mathbf{1 9 8 4}$ & $\mathbf{1 9 8 5}$ & $\mathbf{1 9 8 6}$ & $\mathbf{1 9 8 7}$ & $\mathbf{1 9 8 8}$ & $\mathbf{1 9 8 9}$ & $\mathbf{1 9 9 0}$ & $\mathbf{1 9 9 1}$ & $\mathbf{1 9 9 2}$ & $\mathbf{1 9 9 3}$ \\
\hline 2108 & 2225 & 2396 & 2270 & 2377 & 2451 & 2642 & 2573 & 2703 & 2278 & 2057 & 2073 \\
\hline $\mathbf{1 9 9 4}$ & $\mathbf{1 9 9 5}$ & $\mathbf{1 9 9 6}$ & $\mathbf{1 9 9 7}$ & $\mathbf{1 9 9 8}$ & $\mathbf{1 9 9 9}$ & $\mathbf{2 0 0 0}$ & $\mathbf{2 0 0 1}$ & $\mathbf{2 0 0 2}$ & $\mathbf{2 0 0 3}$ & $\mathbf{2 0 0 4}$ & $\mathbf{2 0 0 5}$ \\
\hline 2625 & 2795 & 2287 & 2308 & 2332 & 2559 & 2707 & 2840 & 2999 & 3197 & 3396 & 3787 \\
\hline $\mathbf{2 0 0 6}$ & $\mathbf{2 0 0 7}$ & $\mathbf{2 0 0 8}$ & $\mathbf{2 0 0 9}$ & $\mathbf{2 0 1 0}$ & $\mathbf{2 0 1 1}$ & $\mathbf{2 0 1 2}$ & $\mathbf{2 0 1 3}$ & $\mathbf{2 0 1 4}$ & $\mathbf{2 0 1 5}$ & $\mathbf{2 0 1 6}$ & $\mathbf{2 0 1 7}$ \\
\hline 4585 & 5209 & 5411 & 5530 & 5730 & 6140 & 6497 & 6838 & 7133 & 7694 & 8061 & 8511 \\
\hline
\end{tabular}

$\mathbf{2 0 1 8}=8821.8$ and by 2019-20 $=9200.0$

Table: 10. GDP Per Capita of Venzuela(1984-2020) [60 ]

\begin{tabular}{|c|c|c|c|c|c|c|c|c|c|c|c|}
\hline 1984 & 1985 & 1986 & 1987 & 1988 & 1989 & 1990 & 1991 & 1992 & 1993 & 1994 & 1995 \\
\hline 3447.45 & 3472.19 & $\begin{array}{l}3488.5 \\
6\end{array}$ & $\begin{array}{l}2619.2 \\
4\end{array}$ & $\begin{array}{l}3292.7 \\
9\end{array}$ & $\begin{array}{l}2378.1 \\
6\end{array}$ & $\begin{array}{l}2492.9 \\
4\end{array}$ & $\begin{array}{l}2685.1 \\
9\end{array}$ & 2968.5 & 2876.08 & $\begin{array}{l}2741.9 \\
8\end{array}$ & $\begin{array}{l}2559.7 \\
7\end{array}$ \\
\hline 1996 & 1997 & 1998 & 1999 & 2000 & 2001 & 2002 & 2003 & 2004 & 2005 & 2006 & 2007 \\
\hline 3174,65 & 3777.79 & $\begin{array}{l}3973,4 \\
2\end{array}$ & $\begin{array}{l}4121.5 \\
8\end{array}$ & $\begin{array}{l}4823.9 \\
6\end{array}$ & $\begin{array}{l}4965.4 \\
1\end{array}$ & $\begin{array}{l}3790.6 \\
6\end{array}$ & $\begin{array}{l}3265.5 \\
5\end{array}$ & 4003.5 & 5418.44 & $\begin{array}{l}6609.9 \\
5\end{array}$ & $\begin{array}{l}8133.3 \\
1\end{array}$ \\
\hline 2008 & 2009 & 2010 & 2011 & 2012 & 2013 & 2014 & 2015 & 2016 & 2017 & 2018 & 2019 \\
\hline $\begin{array}{l}10469.1 \\
7\end{array}$ & 8448.32 & $\begin{array}{l}10324 . \\
8\end{array}$ & $\begin{array}{l}11548 . \\
9\end{array}$ & $\begin{array}{l}11293 . \\
1\end{array}$ & 7869.4 & 7029.9 & $\begin{array}{l}19568 . \\
1\end{array}$ & $\begin{array}{l}90.92 . \\
0\end{array}$ & 4755.0 & $\begin{array}{l}3410.8 \\
5\end{array}$ & $\begin{array}{l}2547.7 \\
8\end{array}$ \\
\hline
\end{tabular}

2427.5(2020) 2409.43(2021) predicted 


\section{LIST OF FIGURES (1-2)}

\section{North Korea and S. Korea}

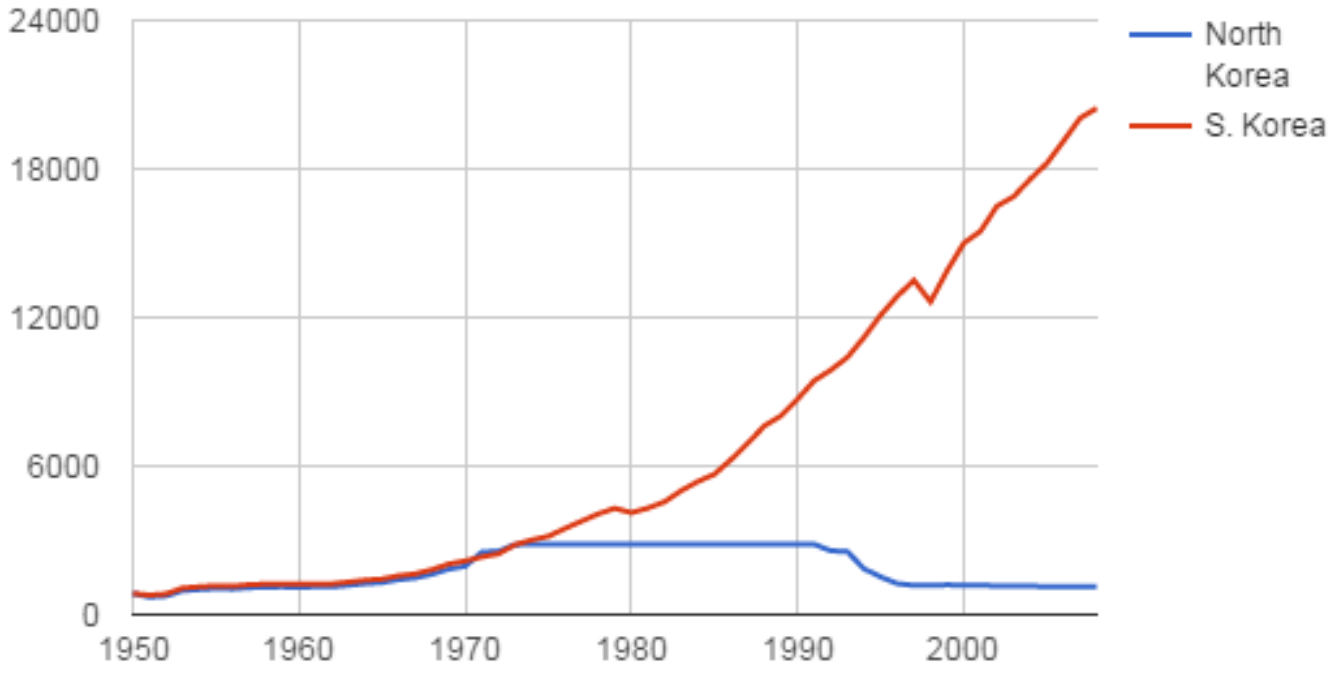

Fig.1. Graphical Representation of GDP per capita (1990 USD), North and South Korea, 1950-200

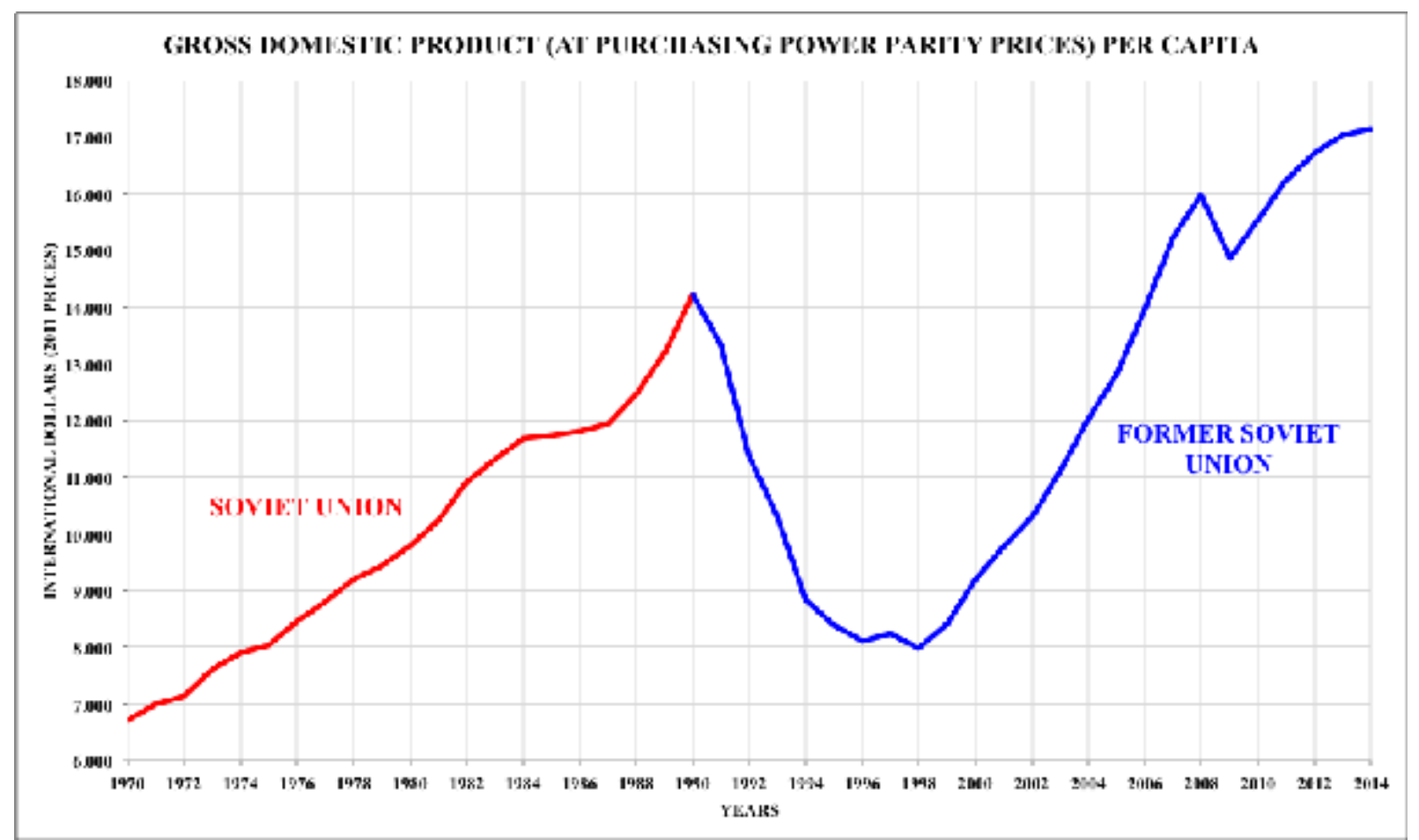

Fig.2.Graphical representation of GDP per capita (USD)[Print From Maddison Project Data] of the Soviet Union (USSR) and Post- split Russia (Former Soviet Union) (1970-2014) 